\title{
THE RELATION OF HOUSING TO TAXATION
}

\author{
HAROLd S. ButTrNhEIM*
}

The housing problem will never be solved while the land problem remains unsolved. The land problem will never be solved while the taxation problem remains unsolved. The taxation problem will never be solved while assessors are required to tax real estate as though land and buildings were one and inseparable.

No system of taxation, even though it be "for revenue only," can fail to aid or injure the general welfare. And no system of real estate taxation can fail to raise or retard the housing standards of the community.

There is, of course, no single solution for the housing problem. Housing is too closely tied up with unemployment, exploitation, lack of city planning and the whole distressing maladjustment of our economic and civic life to be perfectible by any panacea. But a wise use of the taxing power can provide the mental and financial stimuli without which we cannot hope either to banish the slums or to banish the need for governmental subsidies.

Recent years have witnessed a decided trend away from the old general property tax, which aimed to levy at the same rate on all kinds of wealth-real estate, securities, jewelry, furniture and all other property-and to assess it all by the same methods. In thirty-four states the constitution now permits a classified property tax, and eighteen now tax certain intangibles at special low rates. Seven states, including New York, levy no tax on intangibles in the hands of resident owners; and New York in 1933 took the further step of abandoning all attempts to reach personal property through a property tax.

This progress has resulted from a more or less confused realization of the fact that a like treatment applied to radically different elements does not produce similar results in economics any more than in chemistry. The same taxing methods could not be successfully applied alike to real estate, household goods and intangibles. It now appears that we shall find it necessary to go even further and realize that real estate is not a homogeneous form of property, but a dual form which must be broken down into its elements-land and improvements-before we can approach a scientific method of taxation.

- Editor, The American City Magazine. President, General Welfare Tax Leaguc. Member of council and executive committec, National Municipal League. Member of advisory committee, President Hoover's Conference on Home Building and Home Ownership. Member of council, International Federation for Housing and Town Planning. Director, Planning Foundation of America, National Conference on City Planning, National Child Welfare Association. 
In providing the public revenues of any city, the less we tax land the less is the pressure on owners to sell or use the land for housing projects. The less we tax improvements, on the other hand, the greater inducement there is to erect new homes or improve old ones. Obviously, a rational system of real estate taxation will reverse the first trend and strengthen the second. By raising more revenue from the land and less from buildings, two essentials of low-cost housing will be achieved: land will become cheaper to buy and develop, and homes will become cheaper to own or rent.

As I pointed out at the recent National Public Housing Conference in Washington, part of the confusion on this subject in the minds of law-makers and home owners arises from the traditional legalistic use of the term "real estate" as meaning either vacant land alone or land and buildings combined. Lawyers and dictionaries having united in one term two entities as dissimilar as oil and water, tax-makers subserviently follow suit.

Why labor products that happen to be fastened to the land should be taxed at a high rate, while moveable products are taxed at a low rate or not at all, no one has satisfactorily explained. I am not urging, of course, the taxation of moveable products. Personal property -as such products are generally called-has been found to be so unreliable and inequitable a source of public revenue that the personal property tax in most states is either a farce or a corpse. Taxes on homes, however, continue to be exacted, not from any social or economic necessity, but because homes are anchored to the land and are legally classified as a part of real estate. Thus we perpetuate the penalizing of home owners and tenants for their thrift and energy. While doing so we give legal sanction to land holders to collect rents or speculative profits which represent no service which land holders as such have rendered or can render to society.

\section{Proposed Steps Towards Rational Taxation}

Intelligent advocates of housing betterment are giving increasing study to this phase of their problem. Gradually they are realizing the desirability of untaxing buildings and of raising local public revenues largely from the land rents created by governmental expenditures and by the growth or concentration of population. But if theory is to become practice, there arises the practical question of how this rational system of taxation can be adopted with the greatest benefit and least hardship to all concerned. Various proposals for steps to this end have been made, but in few instances as yet have been enacted into law.

The outstanding example of such legislation in the United States is the Pittsburgh "graded tax" plan. Authority for this method of taxation was granted to the secondclass cities of Pennsylvania by the Legislature in $1913 .{ }^{1}$ For the first two years a reduction of ten per cent from the tax levied on land values was allowed on building values. Thereafter, during each successive triennium an additional reduction of

\footnotetext{
${ }^{2}$ Penn. Laws 1913, no. 147, p. 209.
} 
ten per cent was allowed, until the total reduction equaled 50 per cent of the rate on land values. This limit was reached, after the five successive steps, in 1925, and since then Pittsburgh building valuations pay a city tax rate of one-half that levied on land values.

The act provides that land and buildings shall be assessed separately, but without discrimination in the appraisal values for tax purposes. It is entirely a matter of fixing separate tax rates. The Council applies two separate rates, one to apply to the land and the other to buildings. The latter must now be one-half of the former. Strictly speaking, Pittsburgh does not have a tax rate on real estate. Instead it has a land tax and a building tax. No tax whatever is levied on personal property or machinery.

The I933 rate in Pittsburgh (exclusive of Board of Education and County taxes, to which the "graded" plan does not apply) was $\$ 2.06$ on land and $\$ 1.03$ on buildings, on each $\$ 100$ of assessed valuation. The present Mayor of Pittsburgh in his campaign for election last fall advocated legislation to extend this plan by gradual steps until buildings are freed up to 80 per cent from all real estate taxation. Subsequent to his election Mayor McNair undertook to have two important tax measures enacted at the recent special session of the Pennsylvania Legislaturc. One of these bills, which would have reduced the building tax rate to 20 per cent of the land rate, passed the lower house with only eight dissenting votes; and the other bill, applying the graded tax to revenues for the public schools, passed the lower house with only one dissenting vote. There was no vote in the upper house, however, as the bills did not get on the Senate calendar in time for action before the special session adjourned.

Pittsburgh's Chief Assessor, P. R. Williams, writes under date of February 20, I934: "The success of Pittsburgh's graded tax plan is generally recognized, and after twenty years of actual experience no one seriously proposes a return to the old system which prevailed prior to the. Act of rgr3. The present graded tax law has been endorsed and defended by the Allied Boards of Trade of Allegheny County, the Pittsburgh Chamber of Commerce, Pittsburgh Civic Commission, Pittsburgh Real Estate Board, Civic Club of Allegheny County and by various la $\mathbf{a}^{\prime}$ rr unions. A majority of the members of the City Council are on record in favor of extending the present graded tax system and there is substantial evidence of a growing public sentiment in this direction and a strong probability of some important advance during the next year."

An interesting special Act of the Tennessee Legislature, ${ }^{2}$ approved by the Governor on April 2r, I933, gives the Mayor and Aldermen of the little town of Collierville, Tenn., authority to purchase, either on the open market or at tax sales, land within the corporate limits of the town, and to lease this land for the annual economic rent, which is defined in the Act to be "such annual payment for the rent of land as represents the value included in the right to use the bare land, exclusive

\footnotetext{
'Tenn. Priv. Acts 1933, p. I257.
} 
of the value of any character of improvements on said land such as buildings, crops and trees, less any municipal taxes that may be assessed upon the lessee and upon any of said improvements." Leases may extend for not more than 99 years, the annual economic ground rent to be determined each calendar year by the governing body of the municipality.

\section{Other Proposals for Lower Taxes on Buildings}

Numerous suggestions for legislation which would permit discrimination between land and improvements for tax purposes have been made. These fall into three general categories: $(I)$ those that provide for the exemption of improvements without touching upon land taxation; (2) those that provide for the taxation of land without regard to present taxes on improvements; (3) those that provide for a shifting of taxes from improvements to land values.

One of the most important of these proposals was the Grimstad Bill, introduced in 1923 in the Wisconsin Assembly through the influence of Professor John R. Commons. This is similar to the Keller Bill introduced in Congress in I921. ${ }^{3}$ These bills were offered as one of the best and most accurate methods of getting at unearned incomes arising from land ownership. Professor Commons defines unearned incomes as the "incomes which society creates, but the individual does not create."

Increases in land value, resulting from improvements of either a visible or an invisible nature, are considered earned income and exempted from taxation. For example, amounts paid as special assessments are exempted by deducting said amounts from the land value on a graduated scale for 33 years. Improvements, such as clearing land, draining swamps, blasting rocks, and excavating foundations for buildings are treated in the same way. Soil fertility is also exempted, by the simple method of valuing the fertility, if kept at par, at one-half the value of the farm land. In this way one-half the value of kept-up farm land is bare land value subject to the tax, and one-half is soil fertility exempt from the tax, the same as buildings, or special assessments, or other improvements, visible or invisible.

Although neither the Keller nor the Grimstad bill was enacted into law, they are interesting examples of carefully devised legislative proposals in this field.

Measures which would provide other approaches to land or site-value taxation or to the collection by the community of the economic rent, or location rent as some prefer to call it, are now being proposed in some of the states. A constitutional amendment to prohibit the imposition of any sales tax and to provide for the progressive reduction and final extinction of taxation upon improvements and personal property, is being urged in California and has been endorsed by the State Federation of Labor.

Two bills have been drafted in Massachusetts. One aims to amend the long existing betterment tax law, by making the tax applicable to all lands which have been enjoying public improvements without a betterment assessment; no betterment

'67th Cong., Ist Sess. H. R. 6773 . 
tax, however, to be retroactive on such lands. The second bill aims to require automatic reductions in valuations of buildings annually, just as automatic reductions are made in the annual valuation of automobiles. The bill recognizes depreciation in respect to buildings and other improvements. The lack of revenue would be made up by automatically raising the valuation of lands for the purpose of assessment.

A. bill introduced in the 1933 New Jersey Legislature would provide for local option in taxation to the extent of giving to the voters in any taxing district in the state the right to reduce, at the rate of 20 per cent annum for five years, taxes on improvements and on tangible personal property. Thereafter local real estate taxes would be raised wholly by a tax levied upon the true value of the assessable land in the taxing district. "True value" is defined in the bill as the economic rent of land capitalized at 5 per cent per annum; and "economic rent" is defined as that sum for which the bare land would rent per year if let on a long lease.

Another proposal, which in most states might require a constitutional amendment, is to allow an exemption of $\$ 3,000$ or $\$ 5,000$ on each family unit, in assessing new housing for taxation; and to continue to assess at full value the land on which such housing is built. Such a plan was adopted, with a ten-year limitation of tax exemption, in New York ${ }^{4}$ during the housing shortage after the war, and is believed to have been partly responsible for the tremendous building activity which followed.

One of the boldest suggestions yet made-offered last year by a group of optimistic Georgists-would involve an amendment to the Constitution of the State of New York. To Article I, Section ro, which now contains the statement that "The people of this State, in their right of sovereignty, are deemed to possess the original and ultimate property in and to all lands within the jurisdiction of the State," would be added the words "and the annual rent of such lands, being created by the presence and activities of the people, shall be taken for public purposes."

\section{Tax Provisions in Housing Laws}

Such drastic changes in state or municipal revenue systems will be difficult of adoption and hence very slow in their attack on our fundamental problem. Meanwhile, there seems justification for securing, if we can, some special consideration for limited-dividend and public housing projects. Not only may the physical properties and franchises of such projects be relieved from taxation, but exemption may also be given to securities issued by them.

An ingenious provision in the Municipal Housing Authorities Act, ${ }^{,}$adopted by the New York Legislature in January, 1934, provides that "The property of an authority shall be exempt from all local and municipal taxes. An authority shall pay to the city a sum fixed annually. Such sum shall not exceed in any year the sum last levied as an annual tax upon the property of the authority prior to the time of its acquisition by the authority." While this provision will help to lower rents, it would

-N. Y. Laws 1920, c. 949.

'N. Y. Laws 1934, c. 4 . 
probably be more sound and just if the law gave the municipality the option of charging either the tax just mentioned or the current land tax in any future year, whichever might be greater.

In addition to this New York law, public housing legislation has been enacted in recent months in Ohio, ${ }^{6}$ Kentucky, ${ }^{7}$ New Jersey, ${ }^{8}$ Maryland ${ }^{9}$ and Michigan, ${ }^{10}$ authorizing the creation of state, metropolitan, or municipal housing authorities. The Ohio, Kentucky and Maryland laws are silent on the subject of taxation, while those of New Jersey and Michigan stipulate that the property of housing authorities is not tax exempt. ${ }^{11}$

Of the fourteen states having laws providing for state-regulated limited-dividend housing corporations, the California, ${ }^{12}$ Florida $^{13}$ and Illinois ${ }^{14}$ laws are silent on taxation; in those of Ohio, ${ }^{15}$ Arkansas, ${ }^{16}$ Kansas, ${ }^{17}$ South Carolina, ${ }^{18}$ Delaware, ${ }^{19}$ North Carolina, ${ }^{20}$ Texas, $^{21}$ Massachusetts, ${ }^{22}$ and Virginia, ${ }^{23}$ taxation is not mentioned, but a section specifies that provisions of corporation laws apply where not in conflict with the act; in New Jersey a special tax provision was repealed in December, $1933 ;^{24}$ while the New York Act of $1926^{25}$ has tax exemption provisions as follows:

I. Cities are permitted to exempt buildings and improvements, but not land, of 'public' limited-dividend housing corporations from taxation. If advantage is taken of this permission, then such buildings and improvements are exempt from state property taxes. These exemptions do not apply to buildings erected after January $I, 1937 .^{26}$

2. 'Public' limited-dividend housing corporations are specifically exempted from all state non-property taxes including franchise, income, and mortgage registration taxes. ${ }^{27}$

3. Also the income from stocks, and bonds, of 'public' limited-dividend housing corporations is exempt from taxation. ${ }^{28}$

- Ohio Laws 1933, H. B. 19.

${ }^{7} \mathrm{Ky}$. Acts 1933, c. 2.

Md. Laws 1933, c. 32 .

${ }^{10}$ Mich. Pub. Acts 1933, no. 94, p. II7.

${ }^{8}$ N. J. Laws 1933, c. 444 .

"The information on which this and the following paragraph are based was compiled in February, 1934, by Joseph G. Riddle, of the American Legislators' Association. As indicating the recent rapid spread of the movement for public or limited-dividend housing, it is interesting to note that all of this legislation, with the exception of the New York and Ohio limited-dividend laws of 1926 and 1932 respectively, was enacted in 1933 or 1934 .

12 Cal. Stat. 1933, c. 538.

${ }^{23}$ Fla. Gen. Laws 1933, p. 332.

"Ill. Laws x 933, H. B. 622.

${ }^{25}$ Ohio Laws 1932, p. 78.

${ }^{20}$ Ark. Acts 1933, no. 89, p. 267.

${ }^{17}$ Kans. Laws I933, c. 225.

is S. C. Acts 1933, no. 143, p. 176.

"Del. Laws 1933, c. 61.

${ }^{*}$ N. C. Pub. Laws 1933, c. 384 .

${ }^{21}$ Tex. Gen. Laws I933, c. 223.

${ }^{20}$ Mass. Acts 1933, c. 364 .

2 Va. Acts I933, c. 55.

${ }^{24}$ N. J. Laws 1933, c. 426.

${ }^{25}$ N. Y. Laws 1926 , c. 823 .

${ }^{20}$ Ibid. $\$ 39$ (2).

${ }^{27}$ Ibid. $\$ 39$ (1).

* Ibid. $\$ 39$ (2). 
ReLIEF for Real Estate?

One occasionally hears a city planner advocate the British system of "local rating" as less burdensome than the American method of real estate taxation. British citics assess the tenant and not the owner of property, and compute the local tax at a certain percentage of the rent paid. If an owner occupies his own property, the rent is computed on the basis of what it would bring in the market. Property completely unoccupied and unused is exempt from taxation. As Ernest S. Griffith, Professor of Political Science at Syracuse University, has pointed out, ${ }^{29}$ the British system places a sharp penalty upon the development of property-"The higher the tax rate the greater the penalty."

In discussing this same subject, John A. Zangerle, Auditor of Cuyahoga County, Ohio, gives a practical example ${ }^{30}$ of the added burden to owners of income property which would result from the adoption of the British system in an American city:

"By way of illustration suppose that the building value of a city is $\$ 300,000,000$, that the land value is $\$ 300,000,000$, one-half of which, valued at $\$ 150,000,000$, is vacant. To levy $\$ 2.50$ on the $\$ 300,000,000$ building value, plus $\$ 300,000,000$ land value, would produce $\$ 15,000,000$. To produce this $\$ 15,000,000$ on $\$ 300,000,000$ improvement value, plus $\$ 150,000,000$ land value (exempting the vacant $\$ 150,000,000$ ) would require a tax levy of $\$ 3.33$ per \$roo of value assessed."

Many sincere advocates of housing reform in American cities are being proselyted to the worship of false gods by the current agitation for "tax relief for real estate." As The American City pointed out editorially in its issue of March, $1934,{ }^{31}$ many municipal officials, with a laudable desire to help distressed property-owners but with inadequate consideration of how best to do it, are advocating enactment of general sales tax legislation, the proceeds to be so apportioned as to reduce local real estate taxes. If the purpose is to lower the total taxes of the more wealthy property-owners, perhaps a two per cent tax on all retail sales-including food and clothing, as is proposed in bills introduced this year in the New York and New Jersey Legislatures -would accomplish this purpose. But if rent-payers or small-home owners are the expected beneficiaries, the results would be most disappointing. Obviously a general sales tax bears much more heavily on wage earners and small merchants, who must spend most of their income on commodities, than on their wealthier townsmen whose surplus buys investments or personal or professional services. A sales tax, moreover, is a serious drag on the revival of prosperity on which our general welfare now vitally depends.

As was well said by Robert Murray Haig, McVickar Professor of Political Ecunomy at Columbia University, at the 1932 convention of the National Municipal League, "to propose the substitution of general sales taxes for taxes on real estate as a measure of relief for the small man is an.insult to intelligence and an affront to common sense."

$\$ 48$ AMr. CITY 39 (Oct. 1933).

${ }^{20} 49$ Ax. Crty 74 (Feb. 1934).

${ }^{81} 49$ AM. CirY 43 (March, 1934). 
If real estate must have relief from taxation, the public welfare will be advanced, not by the adoption of sales taxes, but by placing more reliance on progressive income and inheritance taxes as sources of governmental revenue. Students of public finance generally have accepted the theory of ability to pay as a proper and desirable basis of taxation. In our present economy, incomes and inheritances form the best index of such ability, and their progressive taxation is the best means of reaching many blocks of taxpaying ability which otherwise will build anti-social fortunes. But assuming that, whether by new taxation or by municipal economies, a reduction in real estate taxes is made possible, the general public can benefit from such reduction, as I have already pointed out, only if the reduction is applied to that part of "real estate" which human labor has created.

A scientific system of taxation will not only make land cheaper to buy and houses cheaper to build and maintain. It will also help to banish that other arch enemy of decent housing-low wages. The surest guarantee of high wages will come, not with the display of a "blue eagle" inside of every shop, but by the display of "help wanted" signs outside of every shop. When the number of jobs seeking workers is permanently greater than the number of workers seeking jobs, wages will exceed a mere subsistence level-and wage earners will be able to pay an economic rent for an adequate home. A wise combination of income, inheritance and land-value taxes would help greatly to hasten that happy day.

\section{A Man and a Book}

This discussion must not close without some reference to the influence of Henry George. Since the publication of "Progress and Poverty" in 1879 , increasing numbers of people in all lands and in all fields of endeavor have come to recognize the essential greatness of its author's personality and the potency of his dominating idea.

While it is true that few economists accept the thesis of the "single tax" in its entirety, yet, as Nicholas Murray Butler testified a short time ago, "it may be said at once that so far as Henry George pointed to privilege as an unbecoming, unfair and indeed disastrous accompaniment of progress, his teaching has passed into economic theory everywhere."

Those of us who would base our system of public revenues on the thricebuttressed foundation which I have proposed, are obviously "triple taxers" rather than "single taxers." But if mankind does ultimately succeed in banishing poverty and in paying for its governmental services largely by the values which such services create, much of the credit will certainly belong to the man who, more than any other who has ever lived, dramatized and vitalized this idea in its economic and ethical implications. And that man was Henry George.

\footnotetext{
s Presidential address, "Progress and Poverty," delivered at the I77th Commencement of Columbia University, June 2, $193 \mathrm{x}$.
} 